\title{
A Sad Bird Learning to Fly: A Dark Real-Life Tale about the Experience of a Patient Suffering Domestic Violence
}

Thiago Henrique Roza, ${ }^{1}$ Sarah Aline Roza. ${ }^{1}$

About the Author: Thiago Henrique Roza is currently a sixth-year medical student at Federal University of Parana, Curitiba, Brazil, of a six-year program.
Submission: Oct 28, 2016 Acceptance: Dec 07, 2016 Publication: Dec 27, 2016

\section{The Experience}

Violence against women, which can be physical, sexual, and psychological, is still a very unfortunate consequence of imbalances of power in a relationship between the aggressor, and the victim.' This type of aggression is a very relevant factor associated with high levels of morbidity and mortality among women. ${ }^{2}$ Mental health problems, for example, are quite common in the victims. ${ }^{3}$ Unfortunately, health professionals, mainly in the Brazilian context, are not prepared for identifying and handling these situations. ${ }^{4-5}$

This is the case of a 44-year-old woman who had attempted to commit suicide for five times. Before our encounter, she had been under the care of several different doctors without any relevant improvement. She was taking Lithium Carbonate (900 mg/day), not on a regular basis, because she reported suffering with gastric disturbances, which she attributed to the medication.

During the medical interview, she reported anhedonia, sleep problems, poor appetite, chronic muscle pains, weight loss, fatigue, suicidal thoughts, intense sadness, depressed mood, irritability, memory problems, lack of proper care with her own health and appearance, feelings of hopelessness, isolation, and low libido. The frequency of her symptoms was on a daily basis, and she was suffering from them for more than a decade.

In the progression of our conversation, I tried to ask about her personal life and relationships. That was the moment when she mentioned her husband for the first time. According to her, she married when she was only fourteen years old, based on promises of eternal love and happiness. However, shortly after the wedding, she discovered the real intentions of the man she had loved. He was a violent and possessive man, who forced her to leave school, and did not allow her to work outside their home. She suffered with constant psychological threats and occasional episodes of physical violence. He was very jealous, not even allowing his wife to spend time at one of her parent's house. It was an oppression that lasted for at least thirty years. It was very painful for her to talk about this kind of relationship, she cried substantially during our conversation.
After our first encounter, she called her 22-year-old son, as a witness of her report. He confirmed all the details of her description, including the psychological, social, economic and physical violence she had suffered for so long. In my attempt of not interfering on her own conclusions about the situation, I tried not to influence her, rather progressively asking her questions about the potential causes of her grief, depression and overall mental health problems. At this moment, both the patient and her son arrived at the conclusion that the husband was the cause of the problem. Subsequently, I presented the possibility in which she could denounce him to the competent authorities, filling out a specific report. Talking to my supervisor and other professionals in that clinic, we presented all the options and measures she could take in that moment, not only for the domestic violence report, but considering the next steps of her new journey. She agreed with it, mentioning that she had never taken such a decision before because of the fear she felt of her husband; however, now she felt much more confident to take the next steps.

In Brazil, cases of domestic violence are considered to be of compulsory notification. ${ }^{6}$ Furthermore, the Brazilian Code of Medical Ethics (Available from: http://www.portalmedico.org. br/novocodigo/integra.asp, updated 2010; cited 2016 Nov 19) states that the doctor is obliged to denounce, to the competent authorities and to the Local branch of the Brazilian Medical Council, cases of domestic violence. ${ }^{6}$ In our case, the health establishment did the official notification, and the patient received the recommendations to go to a specific police department, specialized in cases of domestic violence, in order to fill out a police report. In similar cases, a prompt protective measure usually takes place after the denouncing, in which the aggressor is not allowed to get near the victim.?

Two weeks after, I received a note from a nurse who was a friend of hers, telling me that she was working in a new job and living with her eldest daughter; in addition, she was trying to get used to this new life, which was not exactly easy. It reminded me of an injured bird, just released from its cage; in the beginning, it would find it difficult to fly, as the bird is hurt

Federal University of Paraná, Curitiba, Brazil. 
and sad, frightened by this whole new world of possibilities; however, one day this little bird, preparing for further flights, would ask itself how could it have taken so long.

In conclusion, health professionals should be vigilant about potential cases of domestic violence taking place in the lives of their patients; furthermore, in the Brazilian context, they should be prepared to denounce such cases to the competent authorities.

\section{References}

1. Silva LE, Oliveira ML. Violence against women: systematic review of the Brazilian scientific literature within the period from 2009 to 2013. Cien Saude Colet. 2015 Nov;20(11):3523-32.

2. de Barros ÉN, Silva MA, Falbo Neto CH, Lucena SG, Ponzo L, Pimentel AP. Prevalence and factors associated with intimate partner violence among wo- men in Recife/Pernambuco, Brazil. Cien Saude Colet. 2016 Feb;21(2):591-8. 3. Satyanarayana VA, Chandra PS, Vaddiparti K. Mental health consequences of violence against women and girls. Curr Opin Psychiatry. 2015 Sep;28(5):350-6.

4. Salcedo-Barrientos DM, Miura PO, Macedo VD, Egry EY. How do primary health care professionals deal with pregnant women who are victims of domestic violence? Rev Lat Am Enfermagem 2014 May;22(3):448-53.

5. Da Silva EB, Padoin SM, Vianna LA. Women in situations of violence: limits of assistance. Cien Saude Colet. 2015 Jan;20(1):249-58.

6. Saliba 0, Garbin CA, Garbin A], Dossi AP. [Responsibility of health providers in domestic violence reporting]. Rev Saude Publica. 2007 Jun;41(3):472-7. Portuguese.

7. Alves Eda S, de Oliveira DL, Maffacciolli R. [Repercussions of Maria da Penha law on addressing domestic violence in Porto Alegre]. Rev Gauch Enferm. $2012 \operatorname{Sep} ; 33(3): 141-7$.

\section{Acknowledgments}

The corresponding author would like to acknowledge the help he received from other health professionals and his family medicine supervisor during the course of his family medicine clerkship.

\section{Conflict of Interest Statement t Funding}

The authors have no funding, financial relationships, or conflicts of interest to disclose.

\section{Author Contributions}

Conceptualization, Data collection, Data analysis and interpretation, Writing, Contribution of patients or study materials: THR. Critical revision of the manuscript, Approval of the final version: THR, SAR.

Cite as:

Roza TH, Roza SA. A sad bird learning to fly: a dark real-life tale about the experience of a patient suffering domestic violence. Int J Med Students. 2016 Sep-Dec;4(3):129-30. 